\title{
Study of Al-Karamah and Sharq-Dijla drinking water purification and their byproduct effects on the Tigris River
}

\author{
Khalid A. Rasheed \\ Biotechnology Research Center, Al-Nahrain University
}

\begin{abstract}
Two studied stations were involved in this study included Sharq-Dijla and Al-Karamah water purification stations. Water samples collected from four sites with three replicates for each sample of each site of the river and the station: before, after, inside the stations and at the pipe. The study started in October 2012 to September 2013.
\end{abstract}

Results showed that the minimum level of water temperature was $11^{\circ} \mathrm{C}$ during (December-January) at Sharq-Dijla. While the maximum level was $30^{\circ} \mathrm{C}$ during (August-September) at both AL-Karamah and SharqDijla stations. $p H$ results revealed that the highest level of $p H$ was 8.63 during (October-November) at AL-Karamah station followed by the lowest level was 6.73 in(FebruaryMarch) at Sharq-Dijla station. The highest level of EC was $1068 \mu \mathrm{S} / \mathrm{cm}$ during (April-May) at Sharq-Dijla station, while the lowest level was $693 \mu \mathrm{S} / \mathrm{cm}$ during (August-September) at the same station.

The results of DO showed that the highest level was 11.51 ppm during (December-January) at Sharq-Dijla station, while the lowest level was 4.25 ppm during (AugustSeptember) at AL- Karamah station.The BOD results recorded the highest level of $B O D_{5}$ was 4.49 ppm during (August-September), and the lowest level was $0.67 \mathrm{ppm}$ during (December-January) both results at Sharq-Dijla station.

Total hardness showed that the highest level was about 404 ppm during (December-January) at AL-Karamah station, and the lowest level 162 ppm during (AugustSeptember) at the same station. Free chlorine measurements found with Iraqi limits and WHO for these two stations. The highest value of Iron concentration was 3.30ppm in (December-January) at Al-Karamah station, while the lowest value wasl.63ppm in (AugustSeptember) at Sharq-Dijla station.

Keywords-Tigris River, Al-Karamah, Sharq-Dijla, drinking water, purification.

\section{INTRODUCTION}

Since the dawn of civilization several cities has been built on the banks of the Tigris River along the Baghdad city. To overcome the problem of increased population number, various hydraulic projects have been constructed along the Tigris river, according to reports of Iraqi water resources ministry, during the period of1989-1991, seven water purification units (Sharq- Dijla,Al-Karamah,AlKadsia ,Al-Doura, Al-Wehda, Al-Rasheed and AlWathba stations) were constructed on both AL-Karik and AL-Resafa with limited productionpower. All of those stations were producing potable water enough for four million people, though increasingin population in Baghdad was the most difficult problem, atthe present time population within Baghdad reached until 8-10 million people so the productivity of the potable water purification unit is not enough (Al-Ansari\& Knutsson, 2011).

Enlargement of Baghdad boundaries within past thirty year, had made delivering potable drinking water to the far areas of Baghdad considered as a challenge, polluted drinking water with very low concentration of chlorine was delivered to the limited places of Baghdad, this problem resulted from deficiency in the number of water purification units ,bad situation of the water pipes with taking in consideration that $1000 \mathrm{~km}$ of transporting pipes were changed within the period of 1984-1982(Hamza, 2007).

The aim of this project was to study the characterization of two potable drinking water in Baghdad City and their byproduct effects on the Tigris river.

\section{MATERIALS AND METHODS}

Study area:

Sharq -Dijla and AL-Karamah stations located in the north part of Baghdad city. The distance between these stations is about $7 \mathrm{~km}$ (Figure 1). Three replicate samples were collected from the river representative the left side and the right side of the river and the third replicate from the middle part of the river. 


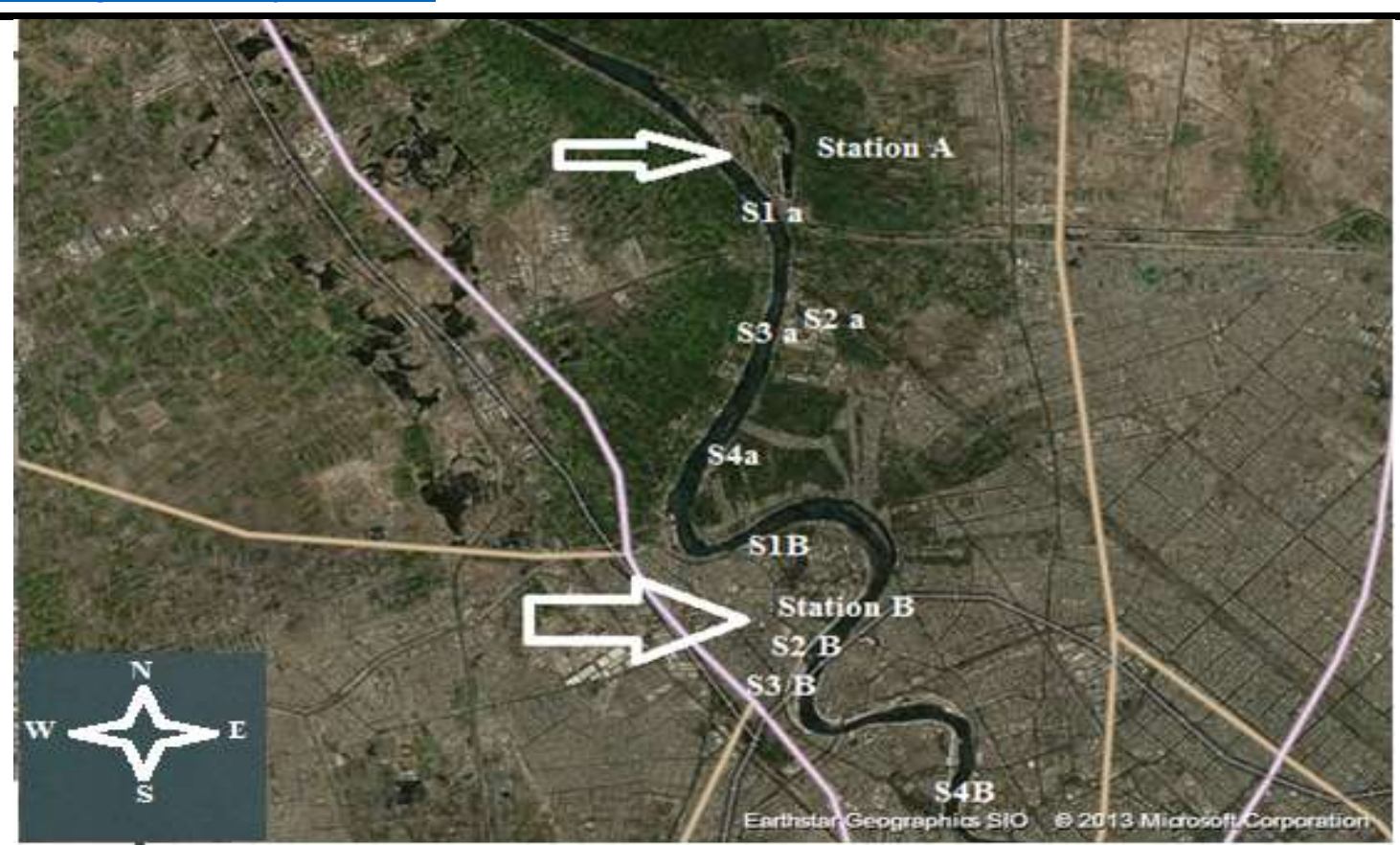

Fig.1: Samplingstation (A) represented Sharq-Dijla station (S1a, S2a, S3a, S4a), (B) represented Al-Karamah station (S1b, $S 2 b, S 3 b, S 4 b)$

\section{Sampling Procedure:}

Sampling was collected bimonthly from October 2012 to September 2013, at the two sites as explained. The samples were taken about $2 \mathrm{~m}$ from the shoreline at a depth of 45-50 cm.

Water samples for dissolved oxygen (DO) and biological oxygen demand $\left(\mathrm{BOD}_{5}\right)$ were collected in $250 \mathrm{ml}$ sterile dark Winkler bottles (washed and sterile by placing them in the oven for $4 \mathrm{hr}$ at $200^{\circ} \mathrm{C}$ ).

\section{Parameter studies}

Temperature:

The Temperature was determined by a mercury thermometer.

$\mathrm{pH}$ :

The $\mathrm{pH}$ was measured by portable $\mathrm{pH}$ meter type Hanna.

Electrical Conductivity (EC):

Measured by using a portable conductivity meter type Siemens. Results were recorded in $\mu \mathrm{S} / \mathrm{cm}$.

\section{$\mathrm{DO}$ and $\mathrm{BOD}_{5}$ :}

The Azide modification method described by APHA (1998) was used for measuring $\mathrm{DO}$ and $\mathrm{BOD}_{5}, \mathrm{BOD}_{5}$ bottles kept in the incubator at $20 \pm 1^{\circ} \mathrm{C}$ for 5 days in the dark then measured as the following:

$\mathrm{BOD}_{5}=\mathrm{DO}$ initial - DO after 5 days in incubator.

Total Hardness T.H.:

According to (Frohlich \&Urish, 2002) the total hardness was calculated according to the following equation:

Total Hardness as $\mathrm{CaCO}_{3} \mathrm{mg} / \mathrm{l}=\frac{A \times B}{\text { ml of sample }} \times 1000$

A: $\mathrm{ml}$ of EDTA used in the titration
B: $\mathrm{mg}$ of $\mathrm{CaCO}_{3}$ equivalent to $1 \mathrm{ml}$ of EDTA

Free Chlorine concentration:

Depending on the color of the concentration of $\mathrm{Cl}$ free chlorine concentration can be determined according to (Senior, 2009)

Fe concentration:

According to (Singer ,2006) using Phenanthroline method was used, the concentration of iron level was measured with $\mathrm{mg} / \mathrm{l}$ according to the equation:

Fe conc. $(\mathrm{mg} / \mathrm{l})=\frac{\text { conc.of standard solution }}{\text { volume of sample }} \times 1000$

\section{Temperature}

\section{RESULTS AND DISCUSSION}

Energy from the sun is the main factor influence air temperature, sunlight and air temperature both influence water temperature, as well as water flow, drought, climatic condition (Ndiongueet al., 2005).

The minimum value of water temperature recorded was $11^{\circ} \mathrm{C}$ during (December-January) at Sharq -Dijla (Figure 2). While, the maximum value of water temperature was $30^{\circ} \mathrm{C}$ during (August-September) at both stations, (Figure 3 ).A significant difference between months at each station was detected, with no significant differences between the sampling location at the same station along the study period.

Temperature showed slight changes between the collection samples because they were at the same geographic location and those changes due to the time difference of collection because some samples were collected in the early morning and other collected on the moon when the sun is vertical to water surface this 
phenomenon were noticed by (Ismail\& Al-Saadi., 2000). The water temperature outside the normal range for a stream or river can cause harm to the aquatic organisms that live there. If the water temperature changes by even a few degrees, it could indicate a source of unnatural warming of the water or thermal pollution (John, 1989).
Inverse correlation recorded between water temperature and dissolved oxygen $(r=-0.139)$. One important aspect of water temperature its effect on the solubility of gases, more gas can be dissolved in cold water than in warm water (Wolf.1998).

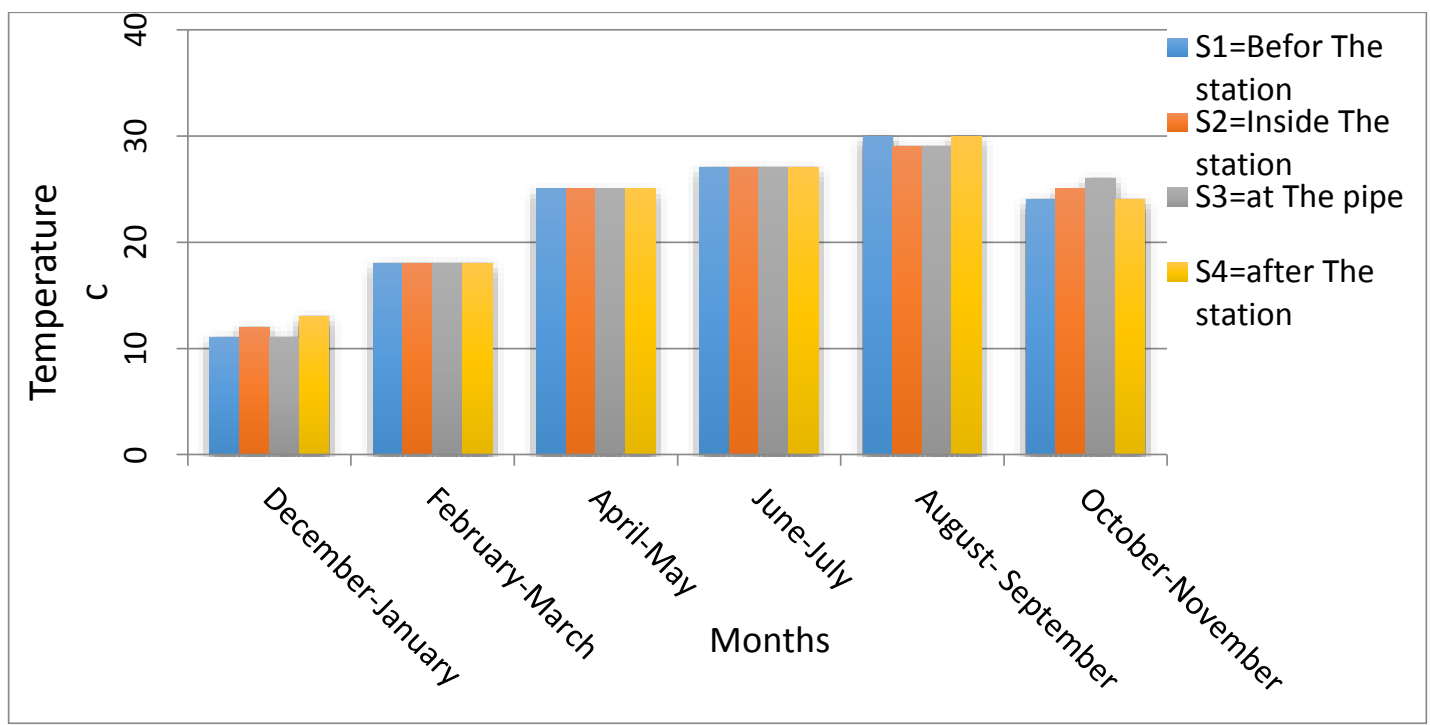

Fig.2: Monthly temperature distribution within locations in Sharq -Dijla station

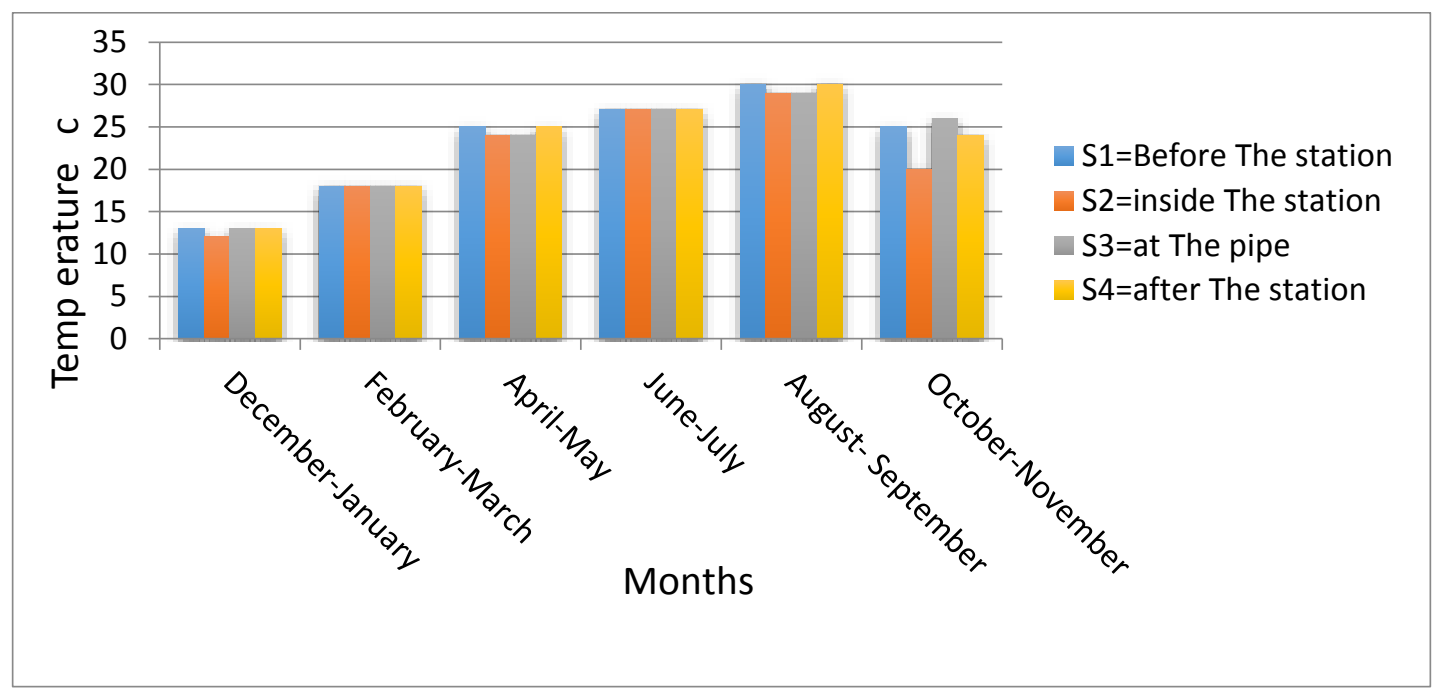

Fig.3: Monthly temperature distribution within locations in AL-Karamah station

$\mathrm{pH}$ values

The $\mathrm{pH}$ value of a water is a measurement of the activity of the hydrogen atom, because the hydrogen activity is a good representation of the acidity or alkalinity of the water (Millero, 2001).

Results showed that the highest value of $\mathrm{pH}$ was 8.63 during (October-November) at AL-Karamah station (Figure 4), while the lowest value was 6.73 during (February-March) at Sharq-Dijla station,(Figure5). The statistical analysis of the data revealed significant differences between months at each station, with no significant differences detected between the sampling www.ijeab.com location at the same station along the study period at $(\mathrm{P}$ $<0.05$ ). The increase of $\mathrm{pH}$ values during (OctoberNovember) may be due to using additional doses of alum article to precipitate calcium carbonate $\left(\mathrm{CaCO}_{3}\right)$ to control pipes corrosion (Reezoqy , 2009), slight decreases of $\mathrm{pH}$ in (February-March) as a result of the dissolving of $\mathrm{CO}_{2}$ in water by drop of temperature which led to form carbonic acid $\left(\mathrm{HCO}_{3}\right)$, which is weak and break down into hydrogen ion which act to when increase it concentration decrease the $\mathrm{pH}$ value (Chapman,1996).These results disagree with Wahab (2010) who stated that the highest value of $\mathrm{pH}$ was in summer. Surface water typically has a 
$\mathrm{pH}$ value between 6.5 and 8.5. The $\mathrm{pH}$ of a water source can vary naturally (WHO, 1996).
While a direct correlation between $\mathrm{pH}$ and water temperature was found $(\mathrm{r}=0.234)$, while direct correlation was noticed between $\mathrm{pH}$ and turbidity $(\mathrm{r}=0.92)$.

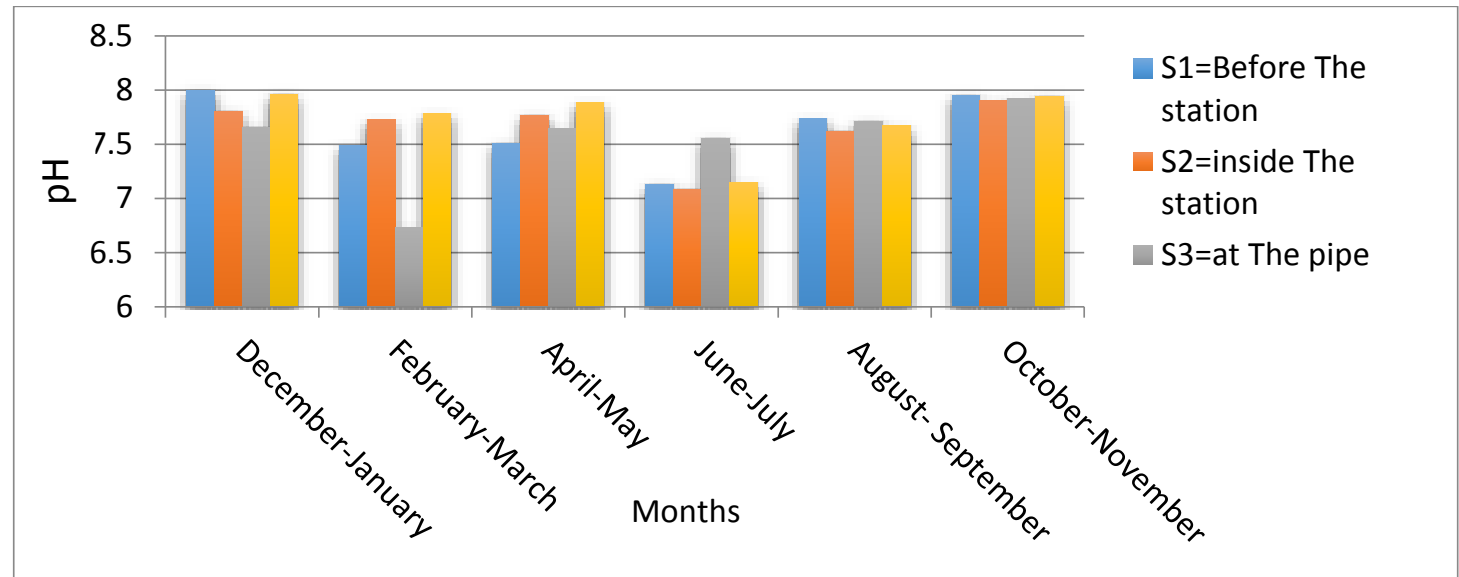

Fig.4: Monthly $p H$ readings within locations in Sharq-Dijla station

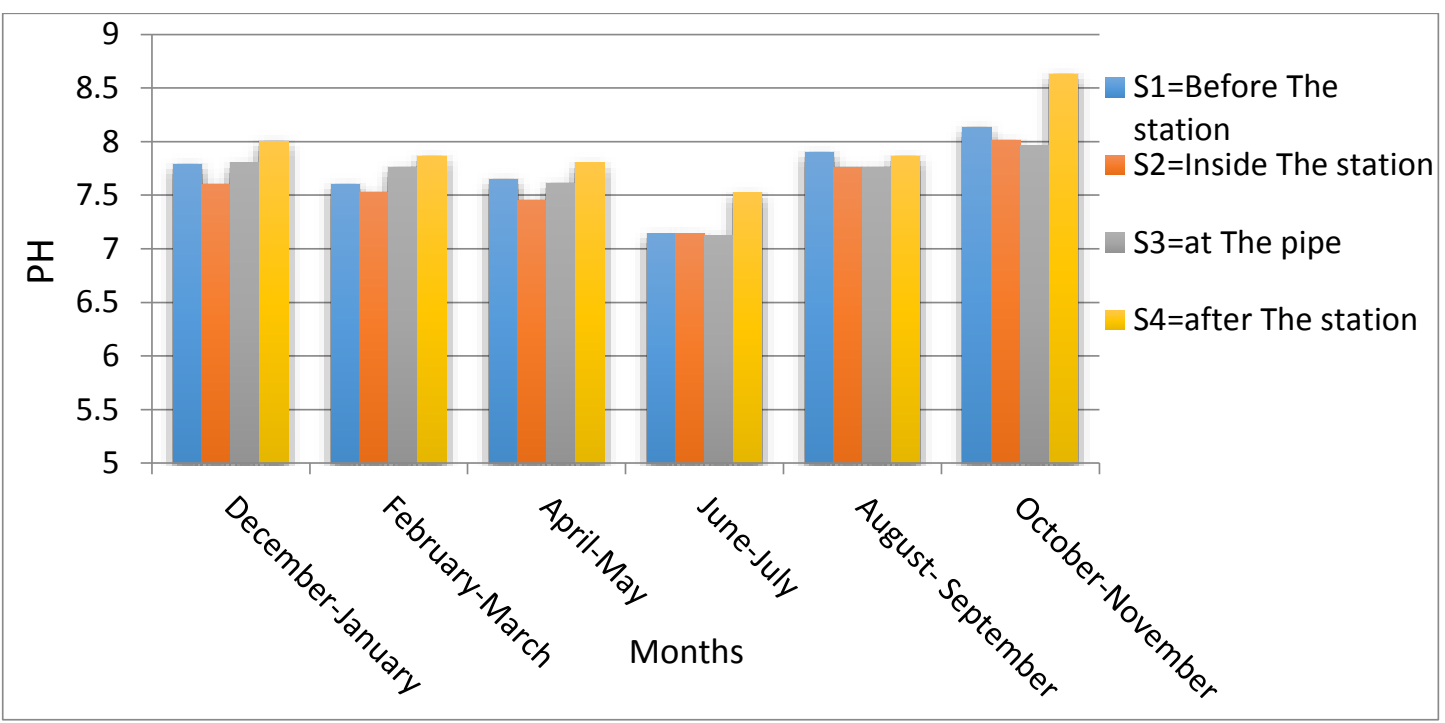

Fig.5: Monthly $\mathrm{pH}$ readings within locations in AL-Karamah station

Electrical conductivity:

Electrical conductivity is the ability of a substance to conduct electricity. The conductivity of water is a moreor-less linear function of the concentration of dissolved ions (Barnes, 2003).

Results showed that the highest value of EC was 1068 $\mu \mathrm{S} / \mathrm{cm}$ during (April-May) at Sharq- Dijla station (Figure 6), while the lowest value was $693 \mu \mathrm{S} / \mathrm{cm}$ during (August-September) at Sharq- Dijla station (Figure 7). The statistical analysis of the data revealed significant differences between months and among sampling location of each station at the same months $(\mathrm{P}<0.05)$. Hashim (2010) showed the same result in his study on the Tigris river. The increase of EC during winter was due to the rains, soil wash and withdraw into the river which helped to increase the dissolved salts and decrease in summer (WHO, 1996). (Hamudat, 2009) stated that the values of EC increased during summer and decreased during winter.

The increase of EC differed with the environmental factor, including temperature and the presence of dissolved ions like $\mathrm{Cl}, \mathrm{K}, \mathrm{Mn}, \mathrm{Na}$. , the increasing and the decrease in E.C. related to dissolve salts rates in water river because E.C. measurement related with total dissolved solids concentration (Rashid , 2001). An inverse correlation was found between E.C. values and water temperature $(\mathrm{r}=-0.145)$, and direct correlation was found between EC and TSS and TDS ( $r=0.204)$.The maximum allowed limit of the EC under (Iraqi laws) is $2000 \mu \mathrm{S} / \mathrm{cm}$. 


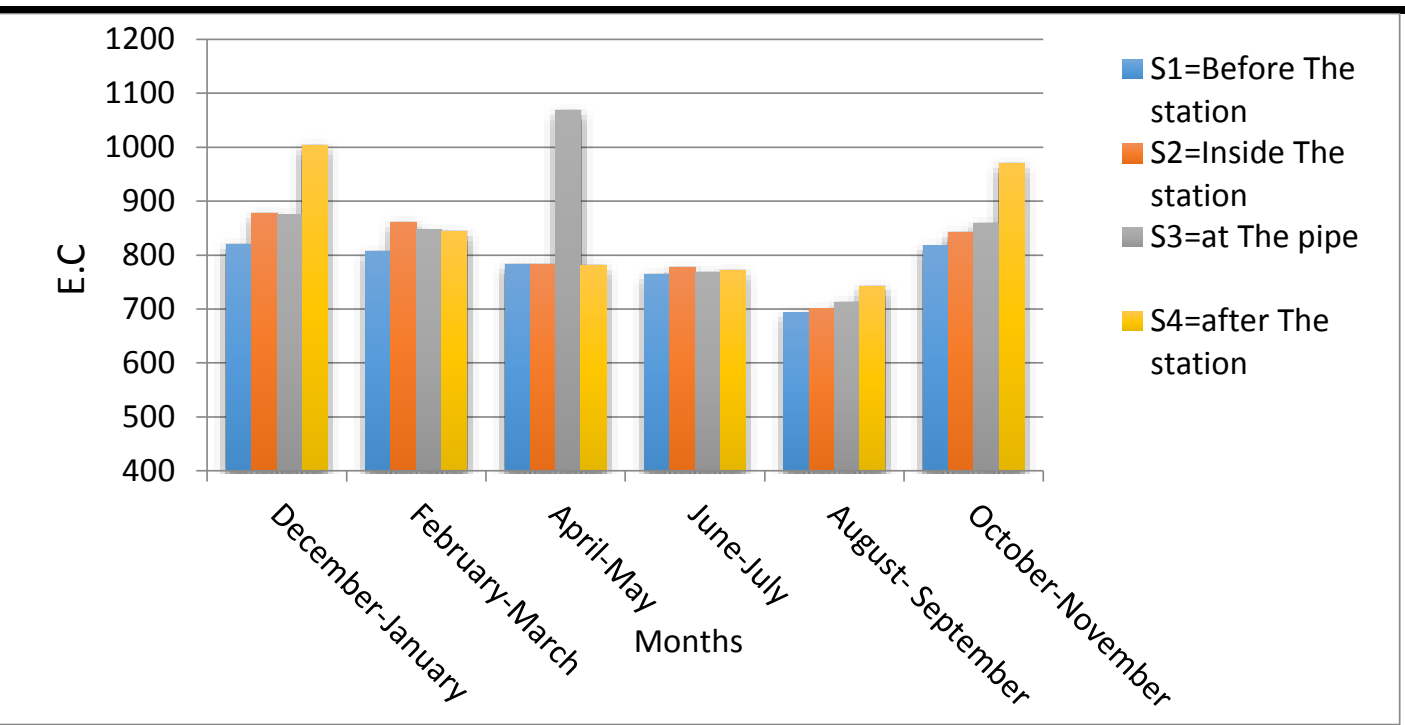

Fig.6: Monthly electrical conductivity variations $(\mu S / \mathrm{cm})$ in Sharq-Dijla station.

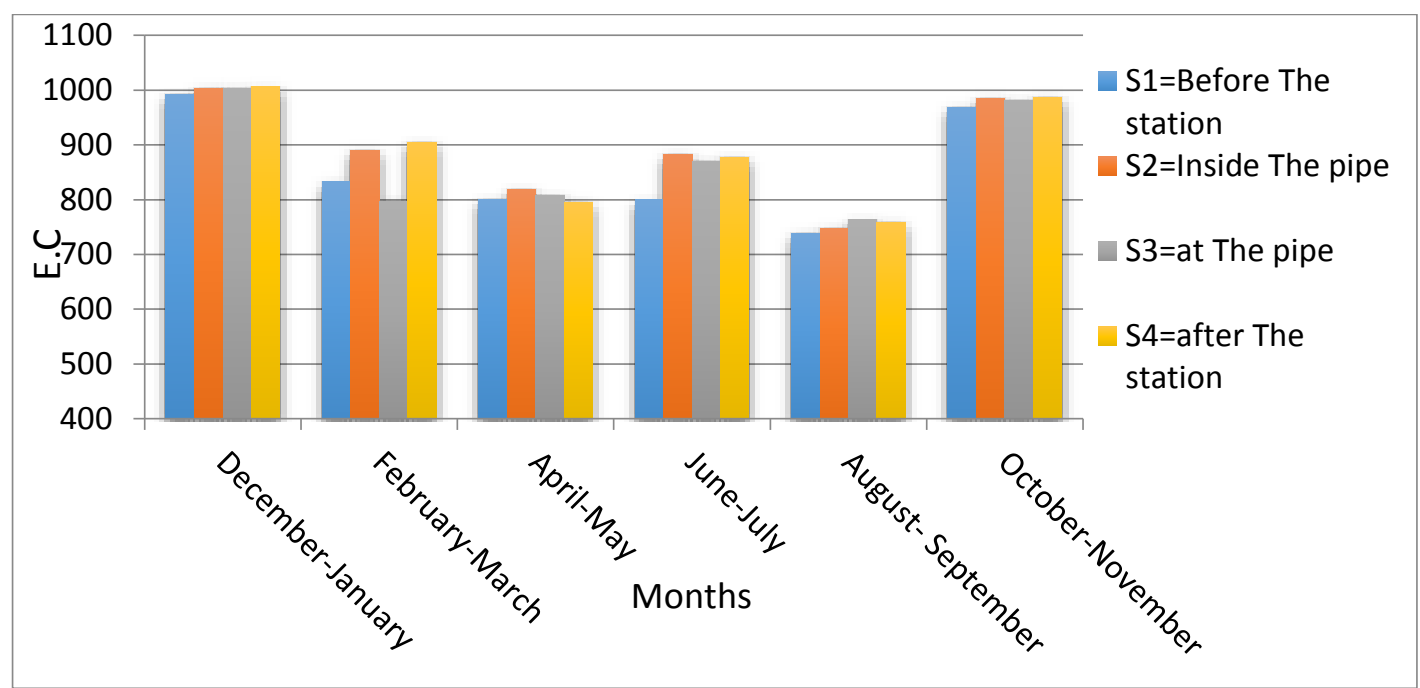

Fig.7: Monthly electrical conductivity variations $(\mu \mathrm{S} / \mathrm{cm})$ in Karamah station.

Dissolved Oxygen:

DO is an indicator of water quality, low levels can produce an aerobic condition leading to smelly water (Pitt, 2000). The measurement of DO can use to indicate the degree of pollution by organic matter, the destruction of organic substances and the level of self-purification of the water (Chapman, 1996).

The results of D.O showed that the highest value of DO was $11.51 \mathrm{ppm}$ in (December-January) at Sharq-Dijla station, while the lowest value was $4.25 \mathrm{ppm}$ in on seasonally or even over 24 hour periods in relation to temperature and biological activity such as photosynthesis and respiration. A significant difference between months and between sampling locations of each station were detected of each station at the same months along the study period. The maximum allowed limit of DO (under Iraqi) laws and WHO was $>5$. Increased temperature accelerates the degradation of organic matter in the overlying water and in bottom deposits which makes an increased demand on DO resources of a given system (Pitt, 2000). 


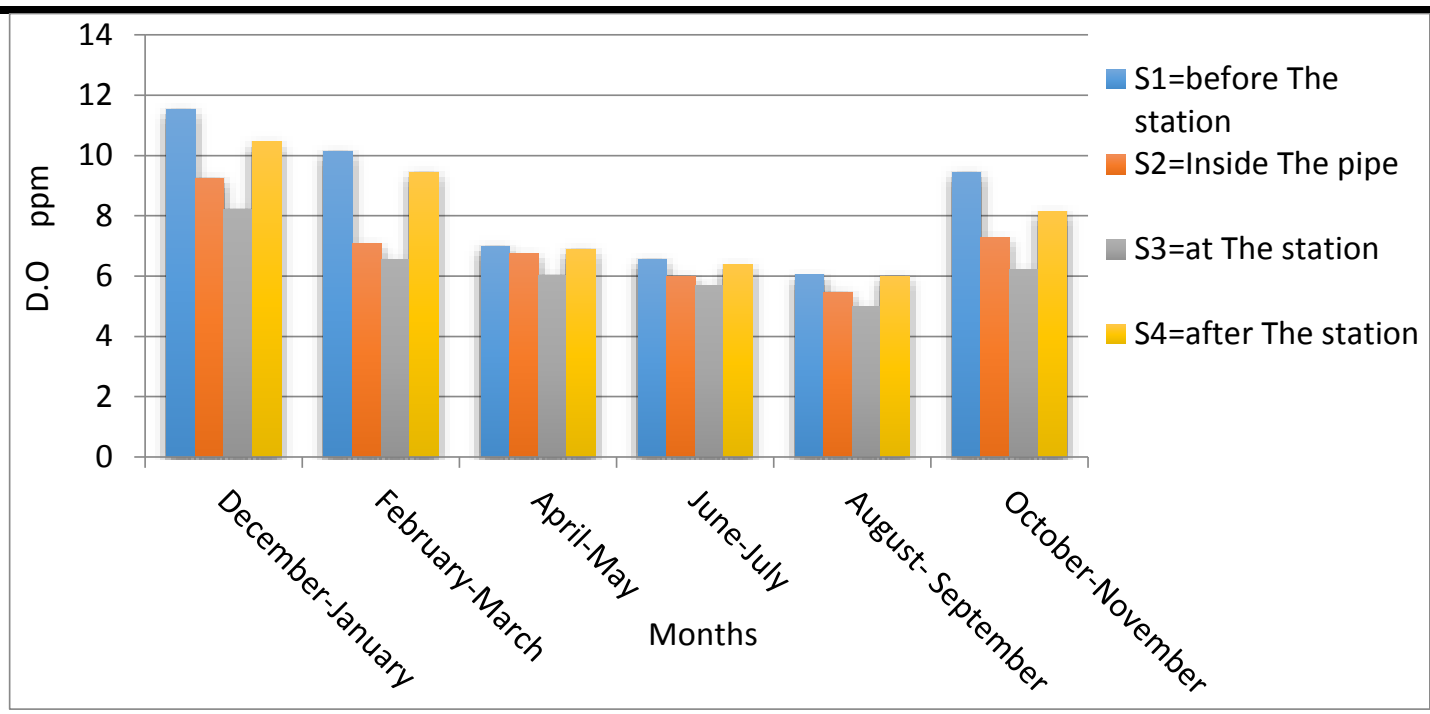

Fig.8: Monthly dissolved oxygen concentrations (ppm) in Sharq-Dijla station

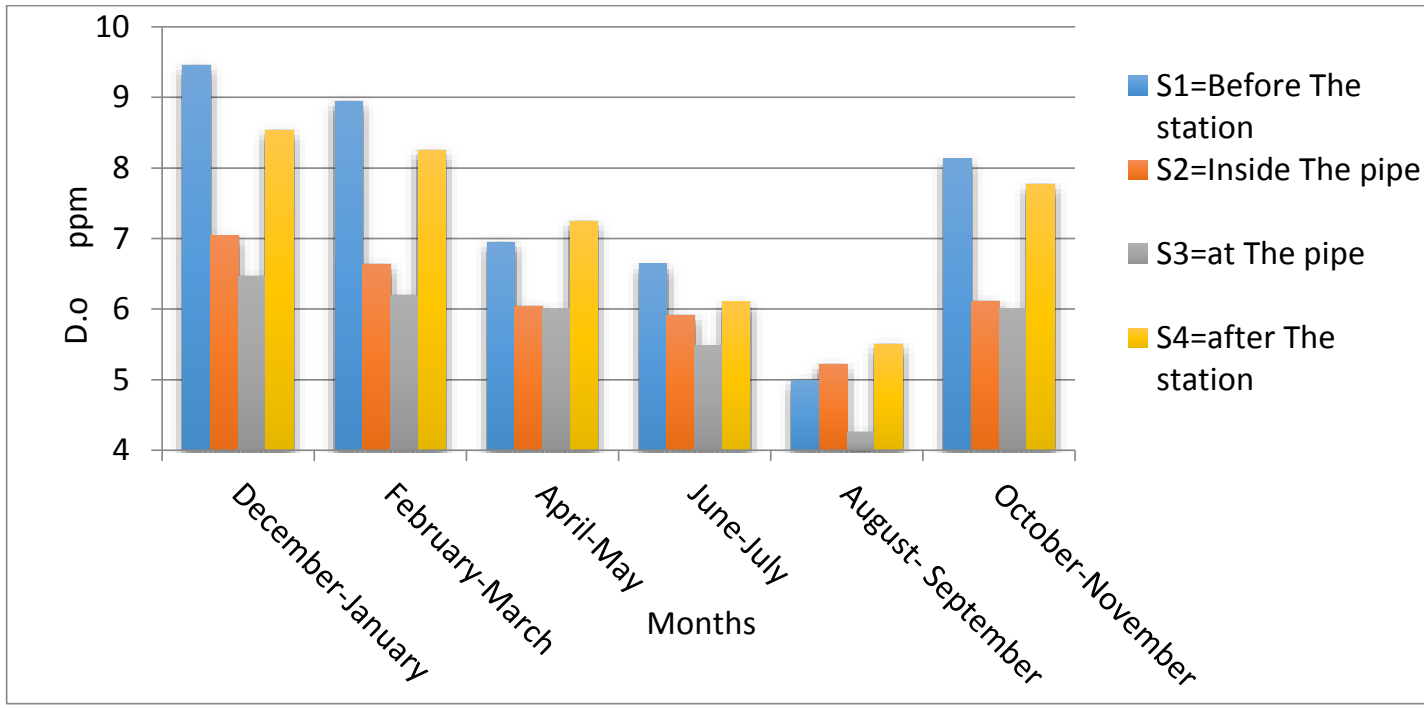

Fig.9: Monthly dissolved oxygen concentration(ppm)in AL-Karamah station

BOD:

Biological Oxygen Demand (BOD) refers to the amount of oxygen that would be consumed if all the organics in one liter of water were oxidized by bacteria and protozoa (Don, 2001).

Results showed that the highest value of the BOD was $4.49 \mathrm{ppm}$ in(August- September)at Sharq-Dijla station, while the lowest value was $0.67 \mathrm{ppm}$ in (DecemberJanuary) at Sharq-Dijla station (Figures 10,11), the increase in BOD values due to the leaking of sewage from broken pipes or sewage treatment stations into the river or may be due to soil wash with heavy rains and domestic discharges (Sabriet al., 2000). If there is a large quantity of organic waste in the water supply, there will also be a lot of bacteria present working to decompose this waste. In this case, the demand for oxygen will be high (due to all the bacteria) so the BOD level will be high. As the waste is consumed or dispersed through the water, BOD levels will begin to decline. Nitrates and phosphates in a body of water can contribute to high BOD levels (Titze\& Walter, 2008).

A significant difference between months and between sampling locations of each station at the same were detected. A direct correlation between BOD and water temperature was found $(\mathrm{r}=0.913)$ and reverse correlation between BOD and DO $\quad(r=-0.243)$. The maximum allowed limits of BOD under (Iraqi laws) and WHO is < 5 . 


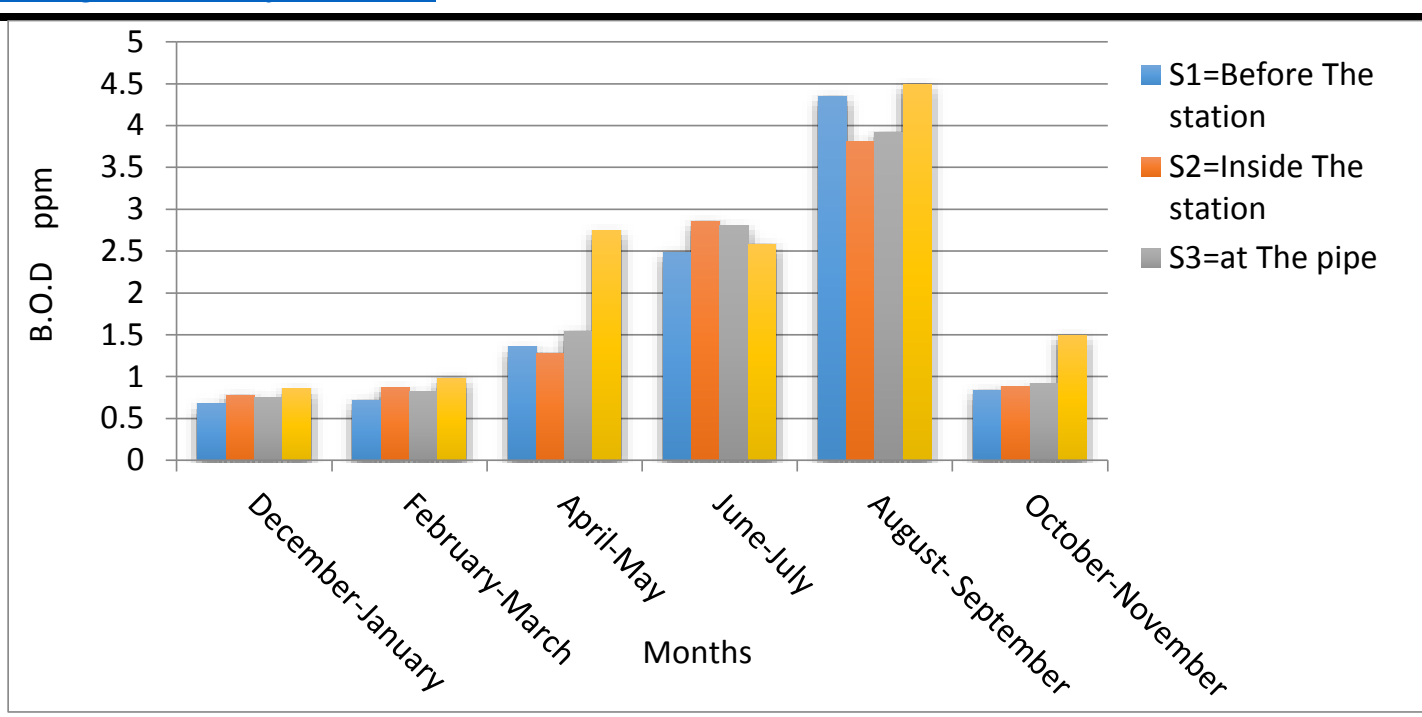

Fig.10: Monthly $\mathrm{BOD}_{5}(\mathrm{ppm})$ recording within locations in Sharq-Dijla station

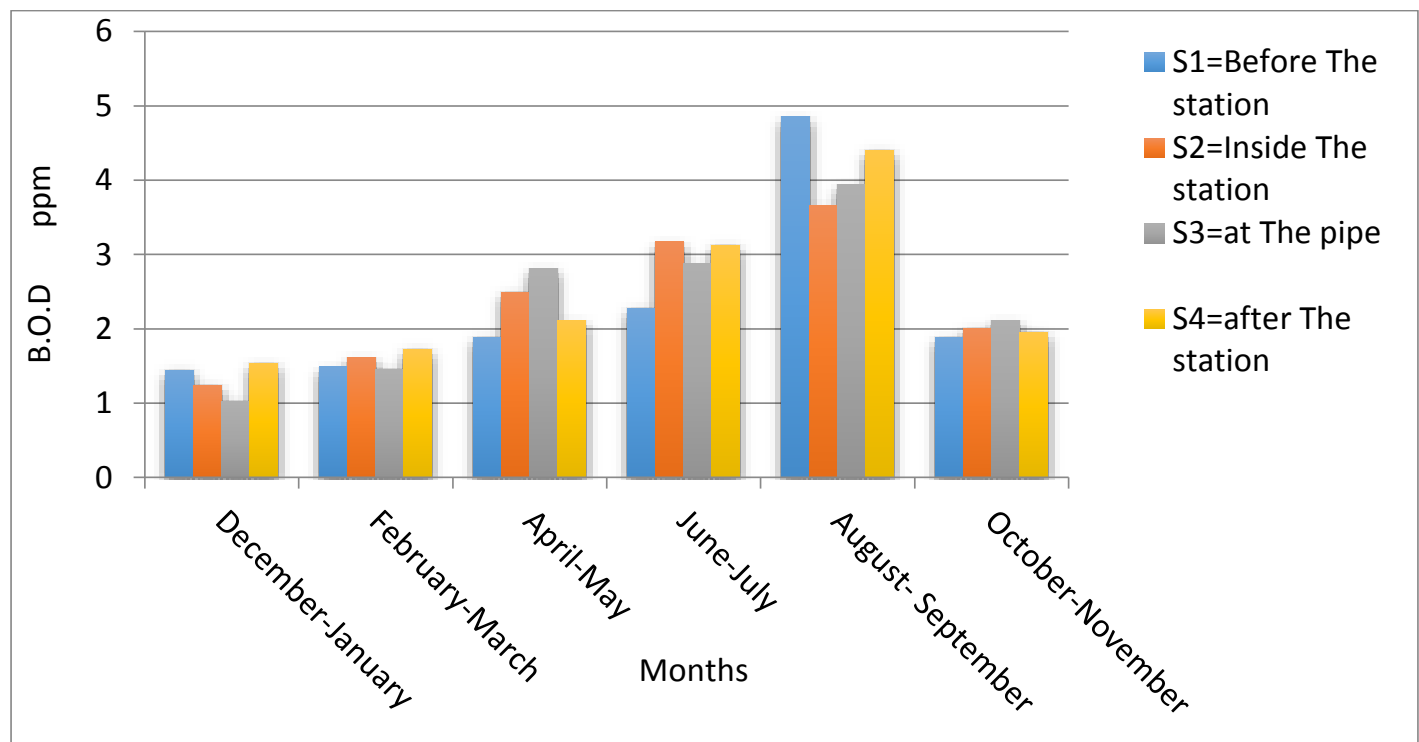

Fig. 11: Monthly $\mathrm{BOD}_{5}(\mathrm{ppm})$ within location in AL-Karamah station

Total hardness:

The natural sources of hardness in water are dissolved polyvalent metallic ions from sedimentary rocks, sewage and runoff from soils. A minor contribution to the total hardness of water is also made by other polyvalent ions, such as aluminum, barium, iron, manganese (Ong et al.,2009).

The highest value of T.H was 404 ppm during (December-January) at AL- Karamah station (Figure 12) and the lowest level 162 ppm during (August- September) at AL- Karamah station (Figure 13). The differences recorded among seasons of total hardness caused by the soil wash out, agricultural flow, or from industrial pollutants. The results showed an increase during the autumn months due to the increase in salt concentrations, especially calcium salt due to the preservation campaign mentioned earlier before to reach a high value in winter because the rainfall. Then increase of material in the water in the lands next to the water sources (Skipton et al., 2004).A significant difference between months at each station and among sampling location of each station at the same months were detected.

Dissolved solids can produce hard water, which leaves deposits and films and on the insides of hot water pipes and boilers. Soaps and detergents do not produce as much lather with hard water as with soft water. As well, high amounts of dissolved solids can corrode pipes, and have a metallic taste. The same minerals that are deposited on these rocks can cause problems when they build up in pipes and(Thomas \& Sach,2000). Inverse correlation between T.H and temperature $(r=-0.558)$ were detected, and direct correlation with turbidity $(\mathrm{r}=0.695)$. 


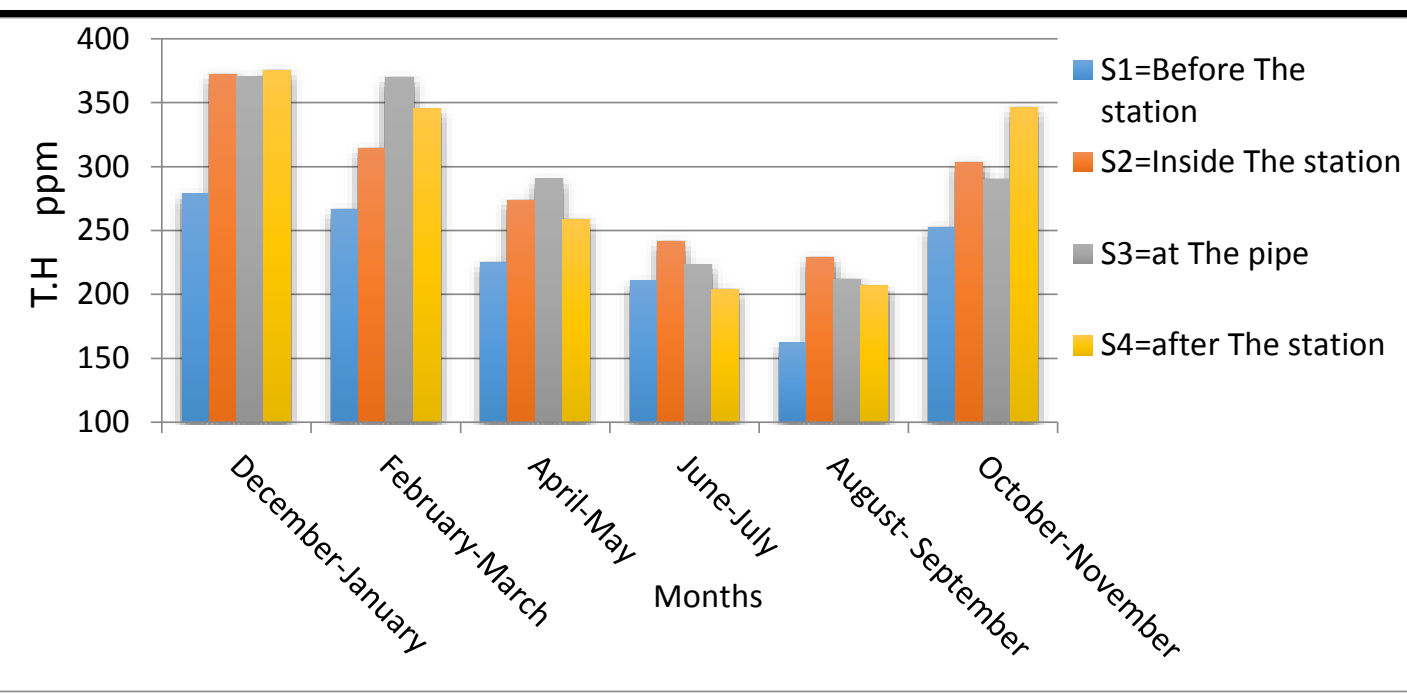

Fig.12: Monthly total hardness concentration (ppm) in Sharq-Dijla station.

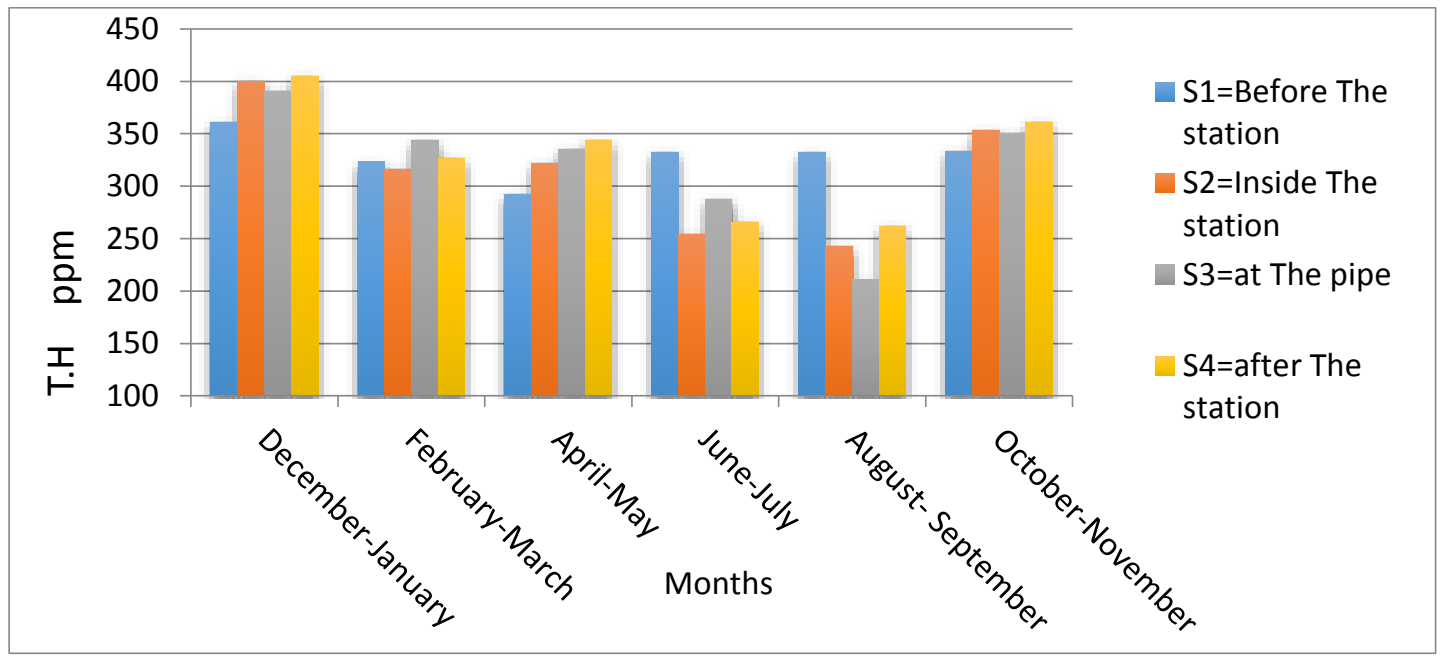

Fig.13: Monthly total Hardness (ppm) within locations in AL-Karamah station

Free chlorine:

If enough chlorine is added, some will remain in the water after all possible organisms have been destroyed. Free chlorine willremain in the water until it is used to destroy new contamination (Davis \& Lambert, 2002)

The results showed that free chlorine was in the acceptable limits at the two stations and the four sampling locations of each station. The statistical analysis showed no significant difference between months of each station along the study period ( $\mathrm{p}>0.05)$. These results agreed with the results of (Al-Qaisi, 2005).

The fall down in free chlorine concentration into normal values due to the decomposition of chlorine when it reacts with water into (HOCL)Hypo chloric acid, this acid decompose rapidly into Hypochlorite ion (WHO,2004). Free chlorine can associate with organic compound within water forming organic halogens this association made free chlorine concentration in water decrease (Volk et al., 2002; Ndiongue et al., 2005).No correlation was detected between chlorine and temperature.
The maximum allowed limit of chlorine under (Iraqi laws) and WHO is $<0.3 \mathrm{ppm}$.

Iron test:

Consequence of the growth of heavy industry has been the addition of high concentrations of heavy metals originating from anthropogenic inputs including industrial wastewater discharges, sewage wastewater, fossil fuel combustion and atmospheric deposition (Mohiuddin et al., 2010).

Results showed that the highest value of Iron concentration was 3.30ppm in (December-January) at AlKaramah station, while the lowest value was $1.63 \mathrm{ppm}$ in (August- September) at Sharq -Dijla station (Figures 14,15). Al-Fatlawey(2007) stated that Iron concentration within river water increased in winter and decrease in summer this increase due to the industrial discharges that contain iron, rains and domestic discharges were considered as one of the main causes of the increase, but this study stated that iron concentration after the station 
was approximately equal to its concentrations before the station.

A significant difference between months and between sampling location of each station at the same months.An inverse correlation was detected between Iron concentration and temperature( $\mathrm{r}=-0.631)$. The maximum allowed limit of iron under (Iraqi laws) and WHO is 0.3 ppm.

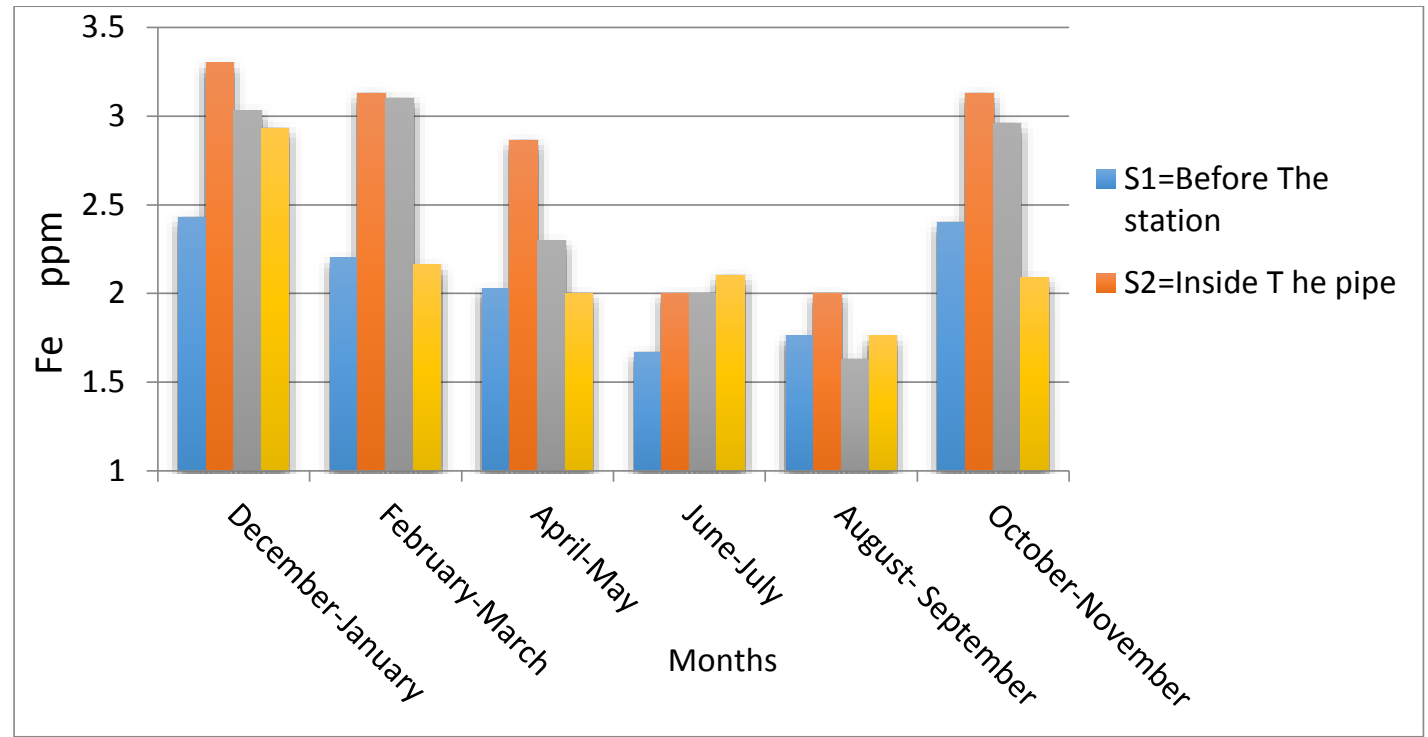

Fig.14: Monthly iron concentration (ppm)within location inSharq-Dijla station

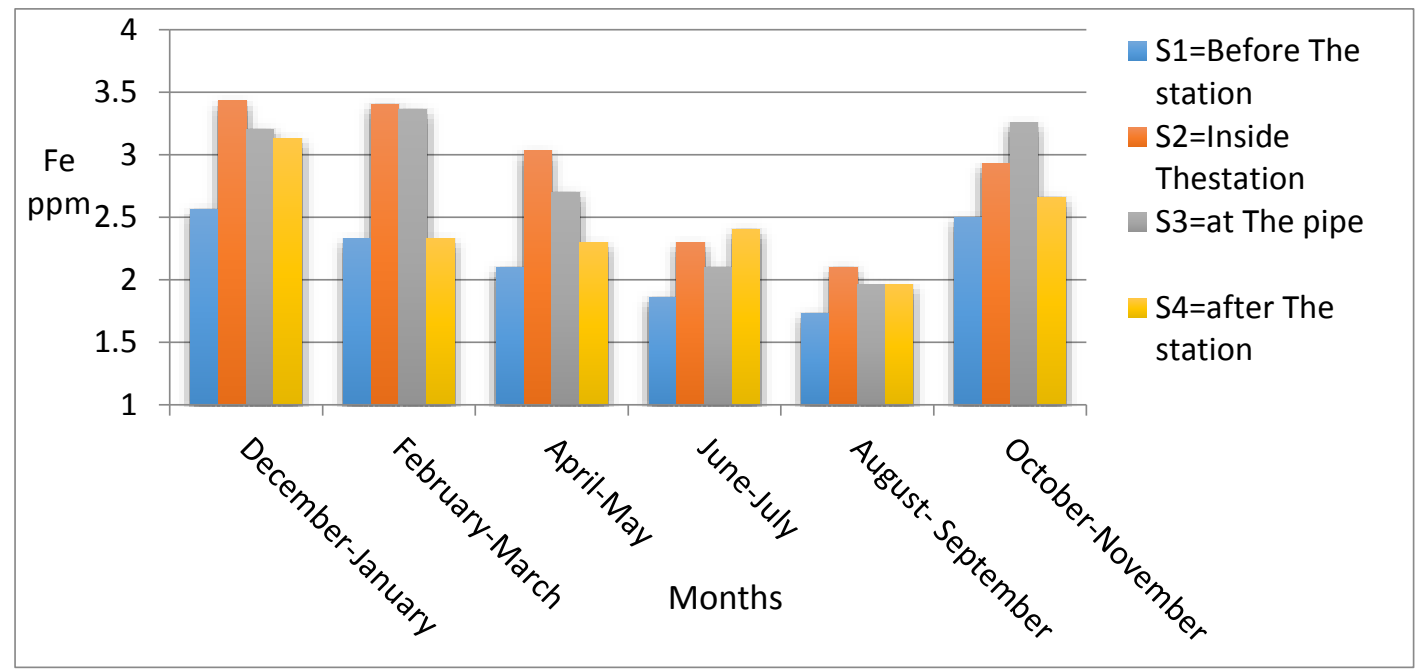

Fig. 15: Monthly iron concentration (ppm) within location in AL-Karamah station

\section{REFERENCES}

[1] Al-Ansari, N. A. and Knutsson,S.2011.Toward Prudent management ofwater resources in Iraq, J. Advanced Science and EngineeringResearch, 1, 5367.

[2] Al-Fatlawey, Y.F.K. 2007.Study the drinking water quality of some Baghdad drinking water treatment stations. Ph.D. Thesis. University of Baghdad (In Arabic).

[3] Al-Qaisi, R. K. J. 2005. Residual chlorine concentrations in Baghdad water supplies, M.Sc., Thesis Building and Constriction, Univ. of Technology
[4] APHA (American Public Health Association). 1998. Standard methods for the examination of water and waste water.20 ${ }^{\text {th }}$ Ed. American Public Health Association, Washington, Dc.

[5] Barnes, V. 2003. Identification of water pollutant in water and air Virginia. Virginia Cooperative Extension Fact Sheet number 427-101. Virginia State University.

[6] Chapman, D. 1996. Ed. Water Quality AssessmentA Guide to use of Biota, Sediment and Water in Environmental Monitoring. $2^{\text {nd }}$ ed. Chapman \&Hall, London. 
[7] Davis J, and Lambert R. 2002. Engineering in Emergencies $2^{\text {nd }}$ edition, chapter 13 . (Undated) Chlorine residual testing.

[8] Don C. 2001.Drinking water treatmentunderstanding the processesand meeting the challenges. Water Science and Technology: Water Supply 1(1):1-7.

[9] Frohlich, R. K. and Urish, D. W.: 2002.The use of geoelectrics and test wells for the assessment ofgroundwater quality of a coastal industrial site', J. Appl. Geophys. 50, 261-278.

[10] HashimN.N.2010.Investigation of Cadmium and Mercury in water, sediments and some benthic invertebrates at section of Tigris river in Baghdad City. M.Sc. thesis, collage of science, University of Baghdad.

[11] HamudatY.R.A.2009. Study the chemical and physical characters of potable water. Msc thesis. College of Science. Baghdad University(in Arabic).

[12] Hamza, J.N. 2007.Impact of Tigris river pollution on the performance of water treatment plants efficiencies in Baghdad city," Iraqi Journal of Chemical and Petroleum Engineering, 9(3):17-24.

[13] Ismail, A. M. and Al-Saadi, H.A. 2000. Comparative limnological study of artificial lake and Tigris River, middle of Iraq. J. Coll. Educ. Women Univ.

[14] John, McPhee,1989.Atchafalaya," in The Control of Nature (New York: Farrar Strauss Girou. $2^{\text {nd }} .88-99$.

[15] Millero, F. J.: 2001. The Physical Chemistry of Natural Waters, Wiley-Interscience, New York.

[16] Mohiuddin, K.M., Zakir, H.M., Otomo, K., Sharmin, S., Shikazono, N., 2010.Geochemical distribution of trace metal pollutants in water and sediments ofdownstream of anurban river. International Journal of Environmental Science and Technology 7 (1), 1728

[17] Ndiongue, S., Huck P.M., and R.M.Slawson. 2005. Effects of temperature and biodegradable organic matter on control of biofilms by free chlorine in a model drinking water distribution system. Water Res. 39: 953 - 964 .

[18] Ong CN, Grandjean AC, Heaney RP .2009. The mineral composition of water and its contribution to calcium and magnesium intake. In: Calcium and magnesium in drinking-water: Public Health Significance. Geneva, World Health Organization: 36-58.

[19] Pitt, R.E. 2000. Water quality conditions in the Cahaba River and likely pollution sources. Department of Civil and Environmental Engineering. University of Alabama.
[20] Rashid, M. J. 2001. Morphology of the sediments in Tigris River curve in Al-Jadriah area. Ms. C. Thesis. Baghdad Univ.

[21] Reezoqy.M.M.S.2009.Study the safety of potable water of a Baghdad.MSc.thesis. College of Science.Baghdad University.

[22] Sabri. A.W.; Ali.Z., Rasheed. K. A.2000. The effect of gulf war on water environment. First scientific convenience of Qatar. Baghdad. 663-672. (in Arabic)

[23] Senior, L.A.2009.Groundwater-quality Assessment.Geological Survey Scientific Investigations Report . vol(12).pp(17-28)

[24] Singer, P. C. 2006. Disinfection byproducts in drinking water:Additional Science and Policy Considerations in the Pursuit ofPublic Health Protection, National Water Research Institute, TheClarke Lecture.

[25] Skipton, S.; D. Varner; P. Jasa; B. Dvorak, and J. Kocher. 2004. Drinking water: hard water. Neb Guide, University of Nebraska Lincoln Extension,Institute of Agriculture and Natural Resources: $4 \mathrm{pp}$.

[26] Thomas KS, Sach T.H. 2000. Multicentre randomized controlled trial of ion-exchange water softeners for the treatment of eczema in children: protocol for the Softened Water Eczema Trial. British Journal of Dermatology, 159(3):561-566

[27] Titze, J., and Walter. H.2008. "Evaluation of a new optical sensor for measuring dissolved oxygen by comparison with standard analytical methods." Monatsschr. Brauwiss.(Mar./Apr.): 66-80.

[28] Volk, C.J., R.Hofmann, G.A.Chauret, G. Rangers, and R.C.Andrews. 2002. Implementation of chlorine dioxide disinfection: effects of the treatment chnge on drinking water quality in a full-scale distribution system. J. Environ. Eng. Sci. 1: $323-330$

[29] Wahab. H.R. 2010. Investigation of lead and chromium in phytoplankton and zooplankton in section of Tigris River at Baghdad City. MS C. thesis, collage of Science, University of Baghdad.

[30] WHO .1996. Guidelines for drinking-water quality 2nd ed. Vol. 2. Health criteria and other supporting information. Geneva, World Health Organization.

[31] WHO .2004. Guidelines for drinking water quality, $3^{\text {rd }}$ ed.Geneva. Switzerland.

[32] Wolf, R.E.1998. Conflict and Cooperation along International Waterways," Water Policy, Vol. 1, No. 2pp. 251-265 